\title{
0 bese women on a low energy rice and bean diet: effects of leucine, arginine or glycine supplementation on protein turnover
}

J.S. Marchini' ${ }^{1}$,

C.R. Lambertini ${ }^{1}$,

E. Ferriolli2 and

J.E. Dutra de Oliveira ${ }^{1}$

\author{
${ }^{1}$ Divisão de N utrição Clínica, and ${ }^{2}$ D ivisão de Medicina Geriátrica e Interna Geral \\ e Laboratório de Espectrometria de M assa, Departamento de Clínica M édica, \\ Faculdade de Medicina de Ribeirão Preto, Universidade de São Paulo, \\ Ribeirão Preto, SP, Brasil
}

\section{Correspondence \\ J.S. Marchini \\ Divisão de Nutrição Clínica \\ FMRP, USP \\ Av. Bandeirantes, 3900 \\ 14049-900 Ribeirão Preto, SP \\ Brasil \\ Fax: + 55-16-633-6695 \\ E-mail: jsmarchi@fmrp.usp.br \\ Research supported by FAPESP (No. 97/09577-4).}

Received August 10, 2000 Accepted June 28, 2001

\section{Abstract}

This study examined if leucine, arginine or glycine supplementation in adult obese patients (body mass index of $33 \pm 4 \mathrm{~kg} / \mathrm{m}^{2}$ ) consuming a Brazilian low energy and protein $\operatorname{diet}(4.2 \mathrm{MJ} /$ day and $0.6 \mathrm{~g}$ protein/ $\mathrm{kg}$ ) affects protein and amino acid metabolism. After four weeks adaptation to this diet, each subject received supplements of these amino acids (equivalent to $0.2 \mathrm{~g}_{\text {protein }} \mathrm{kg}^{-1} \mathrm{day}^{-1}$ ) in random order. On the seventh day of each amino acid supplementation, a single-dose ${ }^{15} \mathrm{~N}$-glycine study was carried out. There were no significant differences in protein flux, synthesis or breakdown. The protein flux (grams of nitrogen, $\mathrm{gN} / 9 \mathrm{~h}$ ) was $55 \pm 24$ during the nonsupplemented diet intake and $39 \pm 10,44 \pm 22$ and $58 \pm 35$ during the leucine-, glycineand arginine-supplemented diet intake, respectively; protein synthesis (gN/9 h) was $57 \pm 24,36 \pm 10,41 \pm 22$ and $56 \pm 36$, respectively; protein breakdown (gN/9 h) was $51 \pm 24,34 \pm 10,32 \pm 28$ and $53 \pm 35$, respectively; kinetic balance $(\mathrm{gN} / 9 \mathrm{~h})$ was $3.2 \pm 1.8,4.1 \pm 1.7,3.4 \pm 2.9$ and $3.9 \pm 1.6$. There was no difference in amino acid profiles due to leucine, arginine or glycine supplementation. The present results suggest that $0.6 \mathrm{~g} / \mathrm{kg}$ of dietary protein is enough to maintain protein turnover in obese women consuming a reduced energy diet and that leucine, arginine or glycine supplementation does not change kinetic balance or protein synthesis.

\section{Introduction}

Obese subjects have increased protein turnover, whole-body protein synthesis and oxidation compared with same age lean adults (1). It has been suggested that protein balance in obese subjects is not maintained with a protein intake lower than $70 \mathrm{~g} /$ day when

\section{Key words}

- O bese women

- Protein

- Glycine

- Arginine

- Leucine

- Stable isotope 
treatment of obesity, but as a source of nitrogen one can expect it to be effective. Moreover, some amino acids have known pharmacological properties which could be of potential benefit for protein metabolism (4), and the effect of supplementation with these amino acids during low energy diets on obese persons has not been reported.

Two amino acids, arginine and leucine, are particularly recognized to have pharmacological in addition to nutritional properties. Arginine (L-2-amino-5-guanidinovaleric acid) is an aliphatic amino acid which has an important role in immune function and stimulates the release of growth hormone by the pituitary gland (5). Arginine is also a physiological precursor of nitric oxide (endothelium-derived relaxing factor) and this has been suggested as an explanation for its hypotensive effect on healthy subjects (6). Leucine (L-2-amino-4-methyl valeric acid) is a branched chain essential amino acid that has important roles in protein and glucose metabolism, neurotransmitter synthesis and lymphoid tissue metabolism (7).

This study was intended to test if supplementation with arginine and leucine improves protein and amino acid metabolism in obese patients consuming a low energy diet. To determine if any eventual changes in protein metabolism would be due to their pharmacological properties, we also studied a period of supplementation with glycine, an amino acid with no such effects. All supplementation periods were compared with nonsupplemented (control) ones.

\section{Material and Methods}

\section{Subjects}

Seven obese women aged $36 \pm 8$ years were studied. Each subject underwent detailed clinical evaluation and blood tests (complete hematologic cell count, plasma glucose, creatinine and urea levels) and, apart from obesity, no other acute or chronic ill- nesses were detected. No subjects were pregnant or breastfeeding. After the initial evaluation, a dietary history was obtained and each subject was instructed to eat a local rice and bean diet (see below) and to maintain their usual level of activity.

This study was approved by the local Ethics Committee. Written informed consent was obtained from each subject after detailed information about the purposes and risks of this research.

\section{Study design}

Each volunteer received a low energy rice and bean diet $(4.2 \mathrm{MJ})$ with a total protein intake of $0.6 \mathrm{~g} \mathrm{~kg}^{-1}$ day $^{-1}$ throughout the 8-week study period. This diet, which has been used in previous similar research protocols, does not have any amino acid deficiency and reflects a typical Brazilian $\operatorname{diet}(8-10)$.

After an adaptation period of 4 weeks, the rice and bean diet was supplemented with leucine, arginine and glycine in random order (equivalent to $0.2 \mathrm{~g}_{\text {protein }} \mathrm{kg}^{-1}$ day $^{-1}$ ) for 7 days each, so that each subject participated in four study periods. Between 7-day supplementation periods, the subjects received a nonsupplemented rice and bean diet for 2 days (washout period). A period of 7 days on a nonsupplemented diet was also studied (control).

On the 7th day of each period, a 9-h whole-body ${ }^{15} \mathrm{~N}$-glycine single-dose study was carried out (11) after a 12-h fast. Each subject was given six isoenergetic, isonitrogenous meals at 2-h intervals, which provided half the total usual daily energy, protein and supplemented leucine, arginine or glycine intake (i.e., $2.2 \mathrm{MJ}, 0.3 \mathrm{~g}$ protein $\mathrm{kg}^{-1}$ day $^{-1}$ from rice and beans, and an amino acid supplement equivalent to $0.2 \mathrm{~g} \mathrm{~kg}^{-1}$ day $\left.^{-1}\right)$. Two hours after the first meal, the bladder was emptied for baseline urine enrichment determination and a dose of ${ }^{15} \mathrm{~N}$ glycine (200 $\mathrm{mg}$ per subject) was given $(0 \mathrm{~h})$. 
All urine was collected until the 9th $\mathrm{h}$ of study for urea and ammonia ${ }^{15} \mathrm{~N}$ enrichment determination. Two blood samples were taken for urea ${ }^{15} \mathrm{~N}$ enrichment determination at $0 \mathrm{~h}$ and $9 \mathrm{~h}(12)$.

\section{Protein turnover}

Flux was calculated from the amount of isotope excreted in urine in the end product (urea and ammonia) over the 9-h study period. In addition, the amount of label retained in the urea pool at $9 \mathrm{~h}$ was used to adjust the result of flux based on the label excreted in urinary urea (13). Flux was calculated as: $\mathrm{Q}=\mathrm{d} \times \mathrm{Ex} / \mathrm{ex}$, where $\mathrm{Q}$ is flux, $\mathrm{d}$ is the amount of isotope administered, Ex is the amount of end product excreted, and ex is the amount of isotope excreted as the end product over the study period. The end product average flux was taken as the harmonic mean of the estimates of flux based on the excretion of urea-N and ammonia- $\mathrm{N}$, and was used in the calculation of protein synthesis and breakdown rates (12). Protein synthesis and degradation were estimated from: $\mathrm{Q}=\mathrm{Nint}+\mathrm{D}=\mathrm{Ex}+\mathrm{S}$, where Nint is nitrogen intake, D is the equivalent of protein degradation, and $\mathrm{S}$ is the equivalent of protein synthesis.

\section{Sample analysis}

Urine was collected into containers with $5 \mathrm{ml}$ concentrated $\mathrm{HCl}$. Samples were stored at $-20^{\circ} \mathrm{C}$ until triplicate analysis. Aliquots were taken for duplicate determination of total nitrogen, ammonia-N, urea-N, ammonia- ${ }^{15} \mathrm{~N}$, urea- ${ }^{15} \mathrm{~N}(14)$ and free amino acids (15). Total nitrogen was measured by the Kjeldahl method. Urea and ammonia were extracted sequentially by Conway diffusion and titration for mass spectrometry analysis by alkaline aeration. Isotope enrichment was measured with a mass spectrometer (Anca 20-20, Europa Scientific, Cheshire, England). Plasma amino acid was analyzed by high- performance liquid chromatography (Shimadzu Corporation, Tokyo, Japan) after precolumn fluorescence derivatization with ortho-phthaldialdehyde (15).

\section{Statistical analysis}

The repeated measures design was used for statistical analysis, with one-way withinsubjects ANOVA (for repeated measures or amino acid supplement). Thus, the repeated measure factor had four levels: no supplement, leucine supplement, glycine supplement and arginine supplement, in random order (16). Post hoc comparisons were made using the Tukey test. Fasted state was compared to fed state by the paired $t$-test. $\mathrm{P}$ values of 0.05 or less were considered significant.

\section{Results}

Anthropometric and biochemical data are shown in Table 1. Body mass index and arm fat index decreased significantly from day one to day 35 (adaptation period) and then remained constant up to the end of the study (Table 1). Blood biochemical data did not change significantly. Urinary urea excretion was higher on the first day of the study as compared to any other study period and urinary urea excretion remained constant from week 2 to 8 .

Subjects 2 and 3 were excluded from the repeated statistical analysis because samples from one study period were lost for both subjects for technical reasons. There were no significant differences in whole-body protein turnover between the period of nonsupplemented rice and bean diet intake and any period of leucine, arginine or glycine supplementation (Table 2). There were also no significant differences in plasma or urinary amino acid profiles between fasted or fed state or between the nonsupplemented and different supplementation periods (Table 3). 
Table 1. Clinical, anthropometric and biochemical data of the volunteers throughout the experimental protocol.

\begin{tabular}{|c|c|c|c|c|c|}
\hline & \multicolumn{5}{|c|}{ Experimental day } \\
\hline & 1 & 35 & 42 & 49 & 56 \\
\hline Heart rate (bpm) & $72 \pm 8(7)$ & - & - & - & $85 \pm 9(6)$ \\
\hline Systolic blood pressure $(\mathrm{mmHg})$ & $120 \pm 6(7)$ & - & - & - & $125 \pm 7(6)$ \\
\hline Diastolic blood pressure (mmHg) & $79 \pm 4(7)$ & - & - & - & $82 \pm 10(6)$ \\
\hline Height $(\mathrm{cm})$ & $156 \pm 7(7)$ & - & - & - & - \\
\hline Arm length (cm) & $35 \pm 3(7)$ & - & - & - & - \\
\hline Triceps skinfold (mm) & $31 \pm 4(7)^{*}$ & $30 \pm 4(7)$ & - & - & $28 \pm 3(6)$ \\
\hline Fat arm index $\left(\mathrm{mm} / \mathrm{dm}^{2}\right)$ & $2.6 \pm 0.5(7)^{*}$ & $2.5 \pm 0.5(7)$ & - & - & $2.3 \pm 0.3(6)$ \\
\hline Arm circumference $(\mathrm{cm})$ & $36 \pm 4(7)$ & $35 \pm 3(7)$ & - & - & $34 \pm 4(6)^{*}$ \\
\hline Muscular circumference $(\mathrm{cm})$ & $26 \pm 3(7)$ & $26 \pm 3(7)$ & - & - & $25 \pm 3(6)$ \\
\hline Weight (kg) & $82 \pm 18(7) *$ & $78 \pm 18(7)$ & $78 \pm 18(7)$ & $77 \pm 18(7)$ & $78 \pm 19$ (6) \\
\hline Body mass index $\left(\mathrm{kg} / \mathrm{m}^{2}\right)$ & $33 \pm 4(7)^{*}$ & $32 \pm 5(7)$ & $31 \pm 5(7)$ & $31 \pm 5(7)$ & $31 \pm 5(6)$ \\
\hline \multicolumn{6}{|l|}{ Blood data } \\
\hline Hemoglobin (g/dl) & $14 \pm 1(7)$ & $13 \pm 1(7)$ & - & - & $13 \pm 1(6)$ \\
\hline Triglycerides (mg/dl) & $140 \pm 39(5)$ & - & - & - & $113 \pm 28(5)$ \\
\hline Cholesterol (mg/dl) & $155 \pm 52(5)$ & - & - & - & $142 \pm 19(5)$ \\
\hline HDL cholesterol (mg/dl) & $30 \pm 2(5)$ & - & - & - & $35 \pm 5(4)$ \\
\hline Albumin (g/l) & $49 \pm 4(7)$ & $53 \pm 4(7)$ & - & - & $50 \pm 5(6)$ \\
\hline Iron $(\mu \mathrm{g} / \mathrm{dl})$ & $72 \pm 12(7)$ & $84 \pm 15(7)$ & - & - & $78 \pm 10(6)$ \\
\hline Total iron-binding capacity $(\mu \mathrm{g} / \mathrm{dll})$ & l) $303 \pm 39$ (7) & $288 \pm 29(7)$ & - & - & $298 \pm 41(6)$ \\
\hline ß-Carotene (mg/dl) & $118 \pm 41(7)$ & $147 \pm 29(7)$ & - & - & $141 \pm 58(6)$ \\
\hline Vitamin A (mg/dl) & $45 \pm 20(7)$ & $36 \pm 7(7)$ & - & - & $35 \pm 18(6)$ \\
\hline Vitamin C (mg/dl) & $0.26 \pm 0.09(7)$ & $0.31 \pm 0.13(7)$ & - & - & $0.25 \pm 0.09(6)$ \\
\hline Glucose (mg/dl) & $95 \pm 6(7)$ & $89 \pm 9(6)$ & - & - & $80 \pm 8(7)$ \\
\hline Folic acid (ng/ml) & $8 \pm 2(6)$ & $7 \pm 1(6)$ & - & - & $13 \pm 1(3)$ \\
\hline \multicolumn{6}{|l|}{ Urine data } \\
\hline Creatinine (g/day) & $1.4 \pm 0.4(6)$ & $1.2 \pm 0.4(7)$ & $1.3 \pm 0.5(7)$ & $1.2 \pm 0.3(7)$ & $1.1 \pm 0.2(5)$ \\
\hline Urea (g/day) & $25 \pm 5(5)^{*}$ & $17 \pm 4(7)$ & - & $14 \pm 4(7)$ & $17 \pm 4(5)$ \\
\hline
\end{tabular}

Data are reported as means $\pm S D$, with the number of subjects given in parentheses. $* \mathrm{P}<0.01$ compared to day 1 (ANOVA/Tukey test). Fat arm index $=$ triceps skinfold/arm length; muscular circumference $=$ arm circumference $-\pi$ triceps skinfold; body mass index $=$ weight/height.

Table 2. Kinetic data after a single dose of ${ }^{15} \mathrm{~N}$-glycine during the periods of no supplementation and supplementation with leucine, glycine or arginine (in random order).

\begin{tabular}{|c|c|c|c|c|}
\hline & No supplement & Leucine & Glycine & Arginine \\
\hline \multicolumn{5}{|c|}{ Total urine nitrogen, urea and ammonia after $9 \mathrm{~h}$ of ${ }^{15} \mathrm{~N}$-glycine infusion (gN/9 h) } \\
\hline Ammonia & $0.22 \pm 0.23$ & $0.26 \pm 0.23$ & $0.15 \pm 0.15$ & $0.18 \pm 0.12$ \\
\hline Urea & $1.04 \pm 1.32$ & $1.33 \pm 0.78$ & $1.32 \pm 0.69$ & $1.22 \pm 0.93$ \\
\hline Total nitrogen & $2.34 \pm 1.80$ & $2.56 \pm 0.93$ & $2.36 \pm 0.73$ & $1.94 \pm 1.14$ \\
\hline \multicolumn{5}{|c|}{ Urine ammonia ${ }^{15} \mathrm{~N}$ enrichment at baseline and after $9 \mathrm{~h}$ of ${ }^{15} \mathrm{~N}$-glycine infusion (atom\% excess) } \\
\hline Baseline & $0.38 \pm 0.01$ & $0.38 \pm 0.02$ & $0.38 \pm 0.01$ & $0.38 \pm 0.01$ \\
\hline After $9 \mathrm{~h}$ & $0.47 \pm 0.04$ & $0.48 \pm 0.05$ & $0.54 \pm 0.15$ & $0.47 \pm 0.07$ \\
\hline \multicolumn{5}{|c|}{ Urine urea ${ }^{15} \mathrm{~N}$ enrichment at baseline and after $9 \mathrm{~h}$ of ${ }^{15} \mathrm{~N}$-glycine infusion (atom\% excess) } \\
\hline Baseline & $0.38 \pm 0.01$ & $0.38 \pm 0.02$ & $0.38 \pm 0.01$ & $0.38 \pm 0.01$ \\
\hline After $9 \mathrm{~h}$ & $0.45 \pm 0.04 a$ & $0.49 \pm 0.02 b$ & $0.48 \pm 0.05 c$ & $0.46 \pm 0.03 d$ \\
\hline \multicolumn{5}{|c|}{ Blood urea ${ }^{15} \mathrm{~N}$ enrichment at baseline and after $9 \mathrm{~h}$ of ${ }^{15} \mathrm{~N}$-glycine infusion (atom\% excess) } \\
\hline Baseline & $0.38 \pm 0.01$ & $0.38 \pm 0.01$ & $0.37 \pm 0.05$ & $0.38 \pm 0.01$ \\
\hline After $9 \mathrm{~h}$ & $0.41 \pm 0.02$ & $0.40 \pm 0.02$ & $0.40 \pm 0.02$ & $0.40 \pm 0.01$ \\
\hline \multicolumn{5}{|l|}{ Protein kinetic data (gN/9 h) } \\
\hline Whole-body flux & $55 \pm 23$ & $39 \pm 10$ & $44 \pm 21$ & $58 \pm 33$ \\
\hline Synthesis & $54 \pm 24$ & $36 \pm 10$ & $41 \pm 22$ & $56 \pm 36$ \\
\hline Breakdown & $51 \pm 24$ & $34 \pm 10$ & $32 \pm 28$ & $53 \pm 35$ \\
\hline Balance (synthesis-breakdown) & $3.2 \pm 1.8$ & $4.1 \pm 1.7$ & $3.4 \pm 2.9$ & $3.9 \pm 1.6$ \\
\hline
\end{tabular}

Data are reported as means \pm SD. Repeated ANOVA: $a<b, a<c, a=d, b=c=d . g N=$ grams of nitrogen. 
Table 3. Plasma and urinary amino acids before (fast) and after (fed) the kinetic study in obese subjects receiving a low energy rice and bean diet.

\begin{tabular}{|c|c|c|c|c|c|c|c|c|c|c|c|c|c|c|c|c|}
\hline \multirow[t]{3}{*}{ Supplement } & \multicolumn{8}{|c|}{ Urine data $(\mu \mathrm{mol} / \mathrm{l})$} & \multicolumn{8}{|c|}{ Plasma data $(\mu \mathrm{mol} / \mathrm{l})$} \\
\hline & \multicolumn{2}{|c|}{ Leucine } & \multicolumn{2}{|c|}{ Glycine } & \multicolumn{2}{|c|}{ Arginine } & \multicolumn{2}{|c|}{$\begin{array}{c}\text { Without } \\
\text { supplement }\end{array}$} & \multicolumn{2}{|c|}{ Leucine } & \multicolumn{2}{|c|}{ Glycine } & \multicolumn{2}{|c|}{ Arginine } & \multicolumn{2}{|c|}{$\begin{array}{l}\text { Without } \\
\text { supplemen }\end{array}$} \\
\hline & Fast & Fed & Fast & Fed & Fast & Fed & Fast & Fed & Fast & Fed & Fast & Fed & Fast & Fed & Fast & Fed \\
\hline \multirow[t]{2}{*}{ Alanine } & 145 & 139 & 214 & 143 & 147 & 165 & 128 & 83 & 172 & 260 & 195 & 206 & 147 & 240 & 268 & 171 \\
\hline & 161 & 172 & 116 & 129 & 74 & 197 & 99 & 48 & 93 & 171 & 155 & 118 & 101 & 226 & 191 & 150 \\
\hline \multirow{2}{*}{ Arginine } & 69 & 145 & 249 & 107 & 148 & 111 & 310 & 114 & 409 & 390 & 348 & 292 & 279 & 431 & 400 & 337 \\
\hline & 61 & 161 & 233 & 96 & 139 & 98 & 452 & 77 & 247 & 186 & 197 & 73 & 100 & 270 & 140 & 98 \\
\hline \multirow[t]{2}{*}{ Aspartic acid } & 26 & 39 & 52 & 33 & 27 & 33 & 52 & 39 & 80 & 89 & 55 & 51 & 49 & 69 & 68 & 59 \\
\hline & 21 & 25 & 40 & 27 & 11 & 28 & 43 & 32 & 50 & 36 & 29 & 21 & 14 & 28 & 23 & 10 \\
\hline \multirow[t]{2}{*}{ Glutamic acid } & 53 & 81 & 171 & 60 & 64 & 108 & 86 & 124 & 353 & 412 & 385 & 352 & 313 & 340 & 416 & 365 \\
\hline & 29 & 66 & 142 & 70 & 59 & 143 & 48 & 125 & 162 & 153 & 299 & 65 & 53 & 134 & 132 & 84 \\
\hline \multirow[t]{2}{*}{ Glycine } & 833 & 1753 & 2559 & 2319 & 796 & 1912 & 3706 & 763 & 386 & 307 & 318 & 187 & 140 & 379 & 294 & 188 \\
\hline & 867 & 1980 & 2640 & 3507 & 468 & 2794 & 3796 & 413 & 419 & 209 & 295 & 82 & 79 & 546 & 177 & 112 \\
\hline \multirow[t]{2}{*}{ Isoleucine } & 23 & 62 & 23 & 23 & 11 & 25 & 20 & 11 & 58 & 101 & 67 & 80 & 58 & 72 & 76 & 70 \\
\hline & 20 & 89 & 13 & 22 & 13 & 25 & 15 & 5 & 26 & 109 & 32 & 42 & 10 & 31 & 21 & 19 \\
\hline \multirow[t]{2}{*}{ Leucine } & 28 & 36 & 32 & 35 & 30 & 31 & 45 & 18 & 334 & 371 & 209 & 202 & 160 & 238 & 188 & 186 \\
\hline & 32 & 34 & 17 & 32 & 19 & 34 & 54 & 13 & 206 & 192 & 111 & 68 & 51 & 112 & 94 & 50 \\
\hline \multirow[t]{2}{*}{ Methionine } & 15 & 9 & 18 & 10 & 19 & 12 & 14 & 9 & 134 & 152 & 158 & 74 & 59 & 136 & 171 & 136 \\
\hline & 15 & 7 & 8 & 13 & 12 & 12 & 16 & 6 & 131 & 187 & 196 & 86 & 79 & 198 & 169 & 153 \\
\hline \multirow[t]{2}{*}{ Phenylalanine } & 48 & 52 & 69 & 50 & 48 & 42 & 69 & 36 & 107 & 131 & 85 & 83 & 64 & 110 & 94 & 81 \\
\hline & 37 & 46 & 59 & 65 & 37 & 70 & 62 & 20 & 75 & 58 & 39 & 28 & 23 & 52 & 38 & 26 \\
\hline \multirow[t]{2}{*}{ Serine } & 115 & 109 & 263 & 205 & 84 & 139 & 204 & 115 & 305 & 264 & 181 & 150 & 123 & 343 & 217 & 160 \\
\hline & 136 & 130 & 216 & 339 & 46 & 128 & 210 & 113 & 354 & 111 & 111 & 54 & 65 & 439 & 130 & 73 \\
\hline \multirow[t]{2}{*}{ Threonine } & 149 & 159 & 292 & 231 & 134 & 181 & 221 & 149 & 211 & 210 & 185 & 149 & 135 & 201 & 216 & 170 \\
\hline & 124 & 137 & 116 & 273 & 118 & 200 & 183 & 79 & 144 & 76 & 138 & 51 & 34 & 155 & 76 & 36 \\
\hline \multirow[t]{2}{*}{ Tyrosine } & 63 & 68 & 87 & 71 & 62 & 63 & 102 & 61 & 87 & 95 & 64 & 63 & 53 & 81 & 68 & 64 \\
\hline & 43 & 37 & 52 & 68 & 35 & 58 & 77 & 22 & 65 & 46 & 26 & 24 & 19 & 42 & 28 & 12 \\
\hline \multirow[t]{2}{*}{ Valine } & 20 & 20 & 30 & 19 & 20 & 17 & 35 & 17 & 229 & 215 & 262 & 229 & 197 & 279 & 295 & 245 \\
\hline & 19 & 8 & 17 & 10 & 12 & 18 & 28 & 10 & 131 & 89 & 159 & 58 & 28 & 137 & 128 & 60 \\
\hline
\end{tabular}

Data are reported as means \pm SD.

\section{Discussion}

In this study, a protein intake of $0.6 \mathrm{~g}$ $\mathrm{kg}^{-1}$ day $^{-1}$ was sufficient to maintain protein turnover in obese women on a reduced energy diet. During the experimental protocol, as expected, there was a drop in anthropometric measurements, but from around the fourth week on, after the adaptation period, there was anthropometric and biochemical stabilization. This may reflect the occurrence of energy expenditure reduction in response to the reduced energy intake, a phenomenon demonstrated by other authors (17). For this research, this stabilization represented, in fact, an advantage, as it eliminated the possibility of misinterpretation of results due to changes in body weight.

The rates of whole-body protein flux were measured using a single oral dose of ${ }^{15} \mathrm{~N}$ - 
glycine $(3,13)$. There is evidence that the method of ${ }^{15} \mathrm{~N}$-glycine infusion employed in whole-body protein turnover studies (i.e., constant infusion, repeated or single dose) does not affect the results $(3,13)$. Besides, the use of a single dose permits the repetition of the study for many times, allowing the follow-up of time course changes in protein synthesis and breakdown (3). For wholebody protein turnover studies it is assumed that the nitrogen pool is homogenous and that the nitrogen exchange among different pools is constant under the experimental conditions used. However, the hypothesis of homogeneity and stability of the metabolic pool of body nitrogen is valid only under exceptional circumstances $(12,18)$. For this reason, the fact that in the present investigation the same subject was studied under different conditions seems to be advantageous. Also, since this permitted the comparison of results with baseline and with every other period, any possible methodological problem would have been diluted in the overall experiment (19). Although this method implies an oversimplification of the complex reactions of protein kinetics in vivo, when it is applied under controlled experimental conditions it affords useful information concerning the dynamics of human protein metabolism (20).

Previous studies have shown that $0.6 \mathrm{~g}$ protein $\mathrm{kg}^{-1}$ day-1 is sufficient to keep the nitrogen equilibrium in healthy Brazilian persons on a rice and bean diet $(9,10)$. It is possible that obese subjects have the same protein requirements, which remain unchanged during the low energy diet, as also proposed by others. Solini et al. (21) found no differences in leucine flux, oxidation or non-oxidative disposal between non-diabetic obese women and normal women. Other studies conducted on eutrophic subjects receiving $0.5 \mathrm{~g}_{\text {protein }} \mathrm{kg}^{-1} \mathrm{day}^{-1}(10,22)$ found a kinetic balance close to that of the present study. Vazquez et al. (23) showed that an increase of the protein composition of isoen- ergetic weight reduction diets $(2.5 \mathrm{KJ} /$ day $)$ from 50 to $70 \mathrm{~g}$ /day leads to no changes in nitrogen balance.

In the present study, whole-body nitrogen flux (around 39-58 mg nitrogen $\mathrm{kg}^{-1} \mathrm{~h}^{-1}$ ) was higher than that obtained for control subjects (around 17-46 mg nitrogen $\mathrm{kg}^{-1} \mathrm{~h}^{-1}$ ) $(10,13)$ with a mean body mass index of 25 $\mathrm{kg} / \mathrm{m}^{2}$. Protein synthesis and breakdown were also higher than values reported in the literature for normal body weight individuals $(10,11,22)$ but similar to those reported for obese adolescents (24). One of these studies (10) was done using the same protocol/environmental conditions as the present study. It should also be pointed out that the variation in the data obtained here for obese subjects was similar to that observed in other studies of protein metabolism $(1-3,20,21,24)$.

Leucine, arginine or glycine supplementation $\left(0.2 \mathrm{~g} \mathrm{~kg}^{-1} \mathrm{day}^{-1}\right)$ did not improve kinetic balance or protein synthesis compared with the baseline diet period. It is possible that, as the subjects had no changes in protein metabolism induced by the low energy diet, any eventual effects of supplementation remained undetectable.

Urine and plasma amino acid profile did not show any remarkable differences, with the exception of high mean plasma values for phenylalanine, leucine and methionine when compared to literature values for eutrophic women (25). Plasma amino acid levels were not modified by supplementation. Kihlberg et al. (19) have described high plasma levels of phenylalanine and leucine and also of isoleucine, valine, lysine, tyrosine, proline and glutamic acid in obese women. These results suggest that obese women may have a particular amino acid profile, but this should be confirmed by further studies.

In conclusion, the present study does not support the use of leucine, arginine or glycine supplementation during low energy diets for obese subjects with the objective of decreasing protein breakdown rate and/or 
increasing protein synthesis rate. Obese subjects are able to keep a stable protein metabolism on a diet containing $0.6 \mathrm{~g}$ protein $\mathrm{kg}^{-1}$ day $^{-1}$ and providing an energy intake of 4.2 MJ/day. Further trials with longer follow-up periods are needed to determine if nitrogen kinetic balance is maintained during very low energy treatment regimens (or even drug treatments). In addition, we con- firm that single-dose protein turnover studies are reliable, fast, inexpensive and easy to carry out in hospitalized patients. They can be used in short whole-body protein turnover studies in patients for whom long, continuous isotope infusion with gas and blood collection would be difficult or even impossible.

\section{References}

1. Welle $S$, Barnard RR, Statt $M \&$ Amatruda J M (1992). Increased protein turnover in obese women. Metabolism, 41: 10281034.

2. Oi Y, Okuda T, Koishi H, Waki M, Kurata $M \&$ Nambu $S$ (1987). Effects of lowenergy diets on protein-metabolism studies with [N-15]glycine in obese patients. J ournal of Nutritional Science and Vitaminology, 33: 227-237.

3. Garlick PJ , Clugston GA \& Waterlow J C (1980). Influence of low-energy diets on whole-body protein-turnover in obese subjects. American J ournal of Physiology, 238: E235-E244.

4. Shah OJ, Anthony J C, Kimball SR \& J efferson LS (2000). 4E-BP1 and S6K1: translational integration sites for nutritional and hormonal information in muscle. American J ournal of Physiology, 279: E715-E729.

5. Brittenden J, Heys SD, Miller I, Sarkar TK, Hutcheon AW, Needham G, Gilbert F, McKean M, Ah-See AK \& Eremin O (1994). Dietary supplementation with Larginine in patients with breast cancer (> $4 \mathrm{~cm}$ ) receiving multimodality treatment: report of a feasibility study. British J ournal of Cancer, 69: 918-921.

6. Hishikawa K, Nakaki T, Suzuki H, Saruta T $\&$ Kato R (1991). L-arginine-induced hypotension. Lancet, 337: 683-684.

7. Schauder P, Wahren J, Paoletti R, Bernardi R \& Rinetti M (1992). BranchedChain Amino Acids. Biochemistry, Physiopathology and Clinical Science. 1st edn. Raven Press, New York.

8. Vannucchi $H$, Duarte RMF \& Dutra de Oliveira J E (1981). Nutritive value of a rice and beans based diet for agricultural migrant workers in Southern Brazil. Nutrition Reports International, 24: 129-134.

9. Vannucchi $H$, Duarte RMF \& Dutra de Oliveira J E (1983). Studies on the protein requirements of Brazilian rural workers ("bóias-frias") given a rice and bean diet.
International J ournal for Vitamin and Nutrition Research, 53: 338-344.

10. Marchini J S, Moreira EAM, Moreira MZ, Hiramatsu T, Dutra de Oliveira JE \& Vannucchi H (1996). Whole-body protein metabolism turnover in men on a high or low calorie rice and bean Brazilian diet. Nutrition Research, 16: 435-441.

11. Fern EB, Garlick PJ, McNurlan MA \& Waterlow J C (1981). The excretion of isotope in urea and ammonia for estimating protein turnover in man with [15N]glycine. Clinical Science, 61: 217-228.

12. Fern EB, Garlick PJ \& Waterlow J C (1985). Apparent compartmentation of body nitrogen in one human subject: its consequences in measuring the rate of wholebody protein synthesis with $15 \mathrm{~N}$. Clinical Science, 68: 271-282.

13. Grove $G$ \& J ackson AA (1995). Measurement of protein-turnover in normal man using the end-product method with oral [N-15]glycine - comparison of single-dose and intermittent-dose regimens. British J ournal of Nutrition, 74: 491-507.

14. Waterlow J C, Garlick PJ \& Millward DJ (1978). Protein Turnover in Mammalian Tissues and in the Whole Body. NorthHolland Publishing, Amsterdam, Holland.

15. Lindroth P \& Mopper K (1979). High performance liquid-chromatographic determination of subpicomole amounts of aminoacids by precolumn fluorescence derivatization with ortho-phthaldialdehyde. Analytical Chemistry, 51: 1667-1674.

16. StatSoft (1994). Statistics for Windows: Statistics II. Vol. 3. StatSoft, Inc., Tulsa, OK.

17. Roberts SB, Fuss P, Heyman MB, Dallal GE \& Young VR (1996). Effects of age on energy expenditure and substrate oxidation during experimental underfeeding in healthy men. J ournals of Gerontology. Series $A$, Biological Sciences and Medical Sciences, 51A: B158-B166.

18. Soares MJ, Piers LS, Shetty PS, J ackson AA \& Waterlow JC (1994). Whole-body protein-turnover in chronically undernourished individuals. Clinical Science, 86: 441-446.

19. Kihlberg R, Bark S \& Hallberg D (1982). An oral amino acid loading test before and after intestinal bypass operation for morbid obesity. Acta Chirurgica Scandinavica, 148: 73-86.

20. Winterer J , Bistrian BR, Bilmazes C, Blackburn GL \& Young VR (1980). Whole body protein tumover, studied with ${ }^{15} \mathrm{~N}$-glycine, and muscle protein breakdown in mildly obese subjects during a protein-sparing diet and brief total fast. Metabolism, 29: 575-581.

21. Solini A, Bonora E, Bonadonna R, Castellino $P \&$ DeFronzo RA (1997). Protein metabolism in human obesity: relationship with glucose and lipid metabolism and with visceral adipose tissue. J ournal of Clinical Endocrinology and Metabolism, 82: 2552-2558.

22. Dichi I, Dichi J B, Papini-Berto SJ , Angeleli AYO, Bicudo MH, Rezende TA \& Burini RC (1996). Protein-energy status and N15-glycine kinetic study of Child A cirrhotic patients fed low- to high-protein energy diets. Nutrition, 12: 519-523.

23. Vazquez J A, Kazi U \& Madani N (1995). Protein metabolism during weight reduction with very-low-energy diets: evaluation of the independent effects of protein and carbohydrate on protein sparing. American J ournal of Clinical Nutrition, 62: 93-103.

24. Pencharz PB, Motil KJ, Parsons HG \& Duffy BJ (1980). The effect of an energyrestricted diet on the protein metabolism of obese adolescents: nitrogen-balance and whole-body nitrogen turnover. Clinical Science, 59: 13-18.

25. Lentner C (1984). Geigy Scientific Tables. Vol 3. Physical Chemistry. Composition of Blood. Hematology, Somatometric Data. 8th revised edn. Ciba-Geigy Limited, Basel, Switzerland, 82-83. 